Boston University School of Law

Scholarly Commons at Boston University School of Law

Faculty Scholarship

2004

Forcible Medication for Courtroom Competence: The Case of

Charles Sell

George J. Annas

Follow this and additional works at: https://scholarship.law.bu.edu/faculty_scholarship

Part of the Health Law and Policy Commons 


\title{
Forcible Medication for Courtroom Competence - The Case of Charles Sell
}

\author{
George J. Annas, J.D., M.P.H.
}

The right to refuse treatment is firmly recognized in U.S. law. ${ }^{1}$ Competent persons have the legal right to refuse treatment, even life-sustaining treatment, and incompetent patients can also refuse treatment through an advance directive, by naming a health care agent to make decisions for them or by having a person who knows their wishes express them. ${ }^{2}$

Competence is a legal construct, not a medical or psychiatric one, and it is task-specific. People can be competent to do one thing (such as refuse medical treatment) but not another (such as stand trial and participate in their own defense). Grisso and Appelbaum capture the essence of incompetence as follows: "Incompetence constitutes a status of the individual that is defined by functional deficits (due to mental illness, mental retardation, or other mental conditions) judged to be sufficiently great that the person currently cannot meet the demands of a specific decision-making situation."3

Despite these well-understood principles, some refusals of treatment by persons in state custody remain controversial. Most notably, these involve the forcible administration of psychotropic drugs to a person who is competent to refuse these medications for the purposes of making an accused person competent to stand trial or of maintaining order in prisons. Because any forced treatment of a person in state custody confronts physicians with a potential problem of "dual loyalty," crucial issues in medical ethics are at stake. All these issues were in play when the Supreme Court decided the case of dentist Charles Thomas Sell in the summer of 2003.

THE CASE AGAINST CHARLES SELL

In the majority opinion written by Justice Stephen G. Breyer, the Court describes Sell as a former practicing dentist who had "a long and unfortunate history of mental illness," beginning with inpatient psychiatric treatment in 1982 after he told physicians that the gold he was using for fillings "had been contaminated by communists." ${ }^{4}$ On other occasions he complained that various public officials were trying to kill him, and in 1997 he told a lawenforcement official that he had spoken to God and that "God told me [for] every [Federal Bureau of Investigation] person I kill, a soul will be saved." These beliefs, among others, led psychiatrists to diagnose Sell as having a "delusional disorder." 5

Shortly after making the comment about the Federal Bureau of Investigation (FBI), Sell was charged with submitting false insurance claims. A federal magistrate ordered a psychiatric examination, after which the magistrate concluded that Sell was "currently competent" to stand trial but might have a "psychotic episode" in the future. He released Sell on bail. A grand jury later charged Sell (and his wife) with mail fraud, Medicaid fraud, and money laundering. In early 1998, the government claimed that Sell was trying to intimidate a witness. The magistrate held a bail-revocation hearing at which he described Sell's behavior as "totally out of control," including "screaming and shouting," using "personal insults" and "racial epithets," and spitting in the magistrate's face. ${ }^{4}$ Sell's bail was revoked, and in April 1998 the grand jury issued a new indictment charging him with attempting to murder both the FBI agent who had arrested him and a former employee who planned to testify against him.

In early 1999, Sell asked the magistrate to reconsider his competence to stand trial. He was examined at the U.S. Medical Center for Federal Prisoners in Springfield, Missouri. Thereafter, the magistrate found him "mentally incompetent to stand trial" and ordered that Sell be hospitalized for treatment for up to four months, to determine "whether there was a substantial probability that [he] would attain the capacity to allow his trial to proceed." The test for competence to stand trial is whether the defendant "has sufficient present ability to consult with his attorney with a reasonable degree of rational understanding and a rational as well as a factual under- 
standing of the proceedings against him." 6 Two months later, the staff of the psychiatric facility recommended that Sell take antipsychotic medication. Sell refused, and the medical staff sought judicial approval to administer psychotropic drugs against Sell's will. This doctor-patient standoff is the subject of the lawsuit. ${ }^{4}$

\section{SELL'S MENTAL CONDITION}

The Supreme Court reviewed the lengthy medical and procedural history. A reviewing psychiatrist at the medical center held a hearing and authorized forced administration of drugs, for two reasons: because Sell was "mentally ill and dangerous, and medication [was] necessary to treat the mental illness; and so that Sell would 'become competent for trial." The reviewing official at the medical center agreed. ${ }^{4}$

In the fall of 1999, the magistrate who had sent Sell to the medical center held a hearing at Sell's request and heard testimony that Sell had approached one of the nurses at the medical center, "suggesting that he was in love with her," and "criticized her for having nothing to do with him." The medical center's physicians testified that, given Sell's diagnosis and current beliefs, this behavior "indicated that he was a safety risk even within the institution. ${ }^{4} \mathrm{He}$ was moved to a locked cell. A year later, the magistrate concluded that Sell was "a danger to himself and others at the institution" and that "antipsychotic medication [was] the only way to render him less dangerous." He also concluded that the benefits of these drugs "far outweigh[ed] any risks" and that drug treatment was the only way likely to render Sell competent to stand trial. He therefore ordered forced medication, but he stayed the order so that Sell could appeal to federal court, which Sell did. ${ }^{4}$

A district court judge determined in April 2001 that the magistrate's finding of "dangerousness" was "clearly erroneous," noting that Sell had been returned to an open ward. Nonetheless, the judge found that forced use of antipsychotic drugs was "medically appropriate" and that it was the only "viable hope of rendering the defendant competent to stand trial." ${ }^{4}$ A year later, a divided court of appeals panel agreed that Sell was not dangerous (noting that his behavior "amounted at most to an inappropriate familiarity and even infatuation with a nurse"). Focusing only on the fraud charges (not the attempted-murder charges, which the court declined to consider because it thought the threats may have been simply a manifestation of his delusional disorder), the court ruled that the government has "an essential interest in bringing the defendant to trial" that justified using forced treatment so long as it was "medically appropriate." 5

The Supreme Court agreed to hear Sell's appeal of this decision in order to determine whether the "forced administration of antipsychotic drugs to render Sell competent to stand trial [would] unconstitutionally deprive him of his 'liberty' to reject medical treatment." 4

PRECEDENTS

The Court based its decision on two prior Supreme Court cases, one involving forced medication of a prisoner, the other forced medication of a defendant charged with murder. In the first case, Washington v. Harper, ${ }^{7}$ the Court decided that a prisoner's right "to avoid the unwanted administration of antipsychotic drugs" could be overcome if the state could demonstrate that forced drug treatment was "reasonably related to legitimate penological interests." Such interests did not include using drugs as punishment but did include using them to maintain order in the prison environment. As for due process in making this assessment, the Court concluded that no judicial review or legal representation was required - only the determination by physicians that the drugs were in the inmate's best medical interests. In the words of the Court's ruling, "an inmate's interests are adequately protected, and perhaps better served, by allowing the decision to medicate to be made by medical professionals rather than a judge." 7

The other case, Riggins v. Nevada, ${ }^{8}$ involved the review of a trial court's authorization of the forcible administration of psychotropic drugs to a defendant accused of murder so that he would be competent to stand trial. The Court ruled that the state could overcome the defendant's liberty interest in avoiding forced medication only if it could demonstrate an "essential" or "overriding" state interest and that rendering a person accused of murder competent to stand trial might qualify as such an overriding interest. Due process required that the prosecution demonstrate to a judge that "the treatment with antipsychotic medication was medically appropriate and, considering less intrusive alternatives, essential for the [defendant's] own safety or the safety of others." ${ }^{8}$ The Court reversed Riggins's conviction, because the trial court had not taken into 
account the possibility of trial prejudice resulting from the effects of medication, including the effect of psychotropic drugs on the defendant's "behavior and demeanor." 8 The defendant might, for example, appear to the jury to be a calm, cold-blooded killer owing to the effects of the medication. From these two prior decisions, the Court summarized the state of the law before Sell:

Harper and Riggins indicated that the Constitution permits the Government involuntarily to administer antipsychotic drugs to a mentally ill defendant facing serious criminal charges in order to render that defendant competent to stand trial, but only if the treatment is medically appropriate, is substantially unlikely to have side effects that may undermine the fairness of the trial, and, taking into account less intrusive alternatives, is necessary significantly to further important governmental trial-related interests. ${ }^{4}$

THE GUIDELINES FOR FORCED MEDICATION

Applying these cases to Sell, the Court concluded that a judge could order a defendant involuntarily medicated for the sole purpose of making the defendant competent to stand trial, if the judge made four findings. The first finding is that "important governmental interests are at stake." These interests include not only bringing persons accused of serious crimes to trial in a timely manner but also making sure that the trial is a fair one. The second is that the forced medication "will significantly further" those state interests by making it "substantially likely" that the defendant will be rendered competent to stand trial and "substantially unlikely" that the drug will have effects that could render the trial unfair. The third finding is that the involuntary medication is necessary to further those interests in that "any alternative, less intrusive treatments are unlikely to achieve substantially the same results." The fourth is that the administration of the drug is "medically appropriate, i.e., in situations in the patient's best medical interest in light of his medical condition." Different kinds of antipsychotic drugs and their side effects and success rates must be considered. ${ }^{4}$

The Court underscored that these four findings applied only to forced medication intended to render a defendant competent to stand trial. The criteria for these findings need not be met if the purpose of forced medication is related to a prisoner's dangerousness or to "the individual's own interests where refusal to take drugs puts his health gravely at risk." 4 The Court also noted that medical experts are likely to be most persuasive on the issue of the usefulness of particular drugs to control a patient's potentially dangerous behavior, whereas they will be less informed about "the more quintessentially legal questions of trial fairness and competence." 4

\section{THE DECISION}

Because the district court judge had found Sell not dangerous to himself or to others, and the appeals court had agreed, the Supreme Court assumed that Sell was not dangerous. On the basis of this assumption, the Court overturned the decision of the appeals court to approve the forced medication of Sell "solely to render Sell competent to stand trial." No determination had been made by either the magistrate or the district court judge about the fairness of a trial given the likely effects of specific drugs on Sell, and this failure could have affected the decision. In the Court's words, "Whether a particular drug will tend to sedate a defendant, interfere with communication with counsel, prevent rapid reaction to trial developments, or diminish the ability to express emotions are matters important to determining the permissibility of medication to restore competence, but not necessarily relevant when dangerousness is primarily at issue." ${ }^{4}$ In addition, the Court instructed the lower courts to consider the fact that Sell had already been confined for a long period of time and that this lengthy confinement reduced the government's interest in prosecution. ${ }^{4}$ The order to medicate Sell forcibly was accordingly vacated, and the case remanded for further proceedings.

THE CONFLICTING INTERESTS

This case has attracted wide interest for two main reasons. First, it is about the power of the government to administer drugs forcibly to persons who are competent to decline medication solely to further a governmental interest and not for their health. Second, the treatment involved is aimed at changing the mental functioning of a person and thus raises the issue of whether drugs that affect the brain should be considered in a different way from drugs that affect other parts of the body. 
As to the government's power to compel medical treatment of a competent adult, virtually all commentators and courts agree that such power can be legitimately exercised only in extremely limited circumstances. Harper, which involved the treatment of a potentially dangerous prisoner, is an example of such circumstances. ${ }^{7,9}$ The importance of Harper, however, is limited by the facts that states have broad powers to ensure security inside prisons and that the prisoners' liberty rights are highly circumscribed already. Sell, nonetheless, seemed to expand the decision in Harper by permitting forced treatment of someone who has only been accused of a crime. On the surface, the four criteria established by the Supreme Court may seem stringent. However, the Court's stated belief that there will be circumstances in which a person charged with nonviolent crimes can be forcibly medicated in order to make the person competent to stand trial means that there are no defendants for whom forcible medication is out of bounds as a matter of constitutional law. This is probably why both sides in Sell claimed victory. ${ }^{10}$

I agree with the Court's assertion that there are circumstances in which the state's interest in actually having a trial is very important, but I do not believe that Sell's case should qualify. One case that might meet this test is that of Russell Eugene Weston, Jr., who is charged with murdering two U.S. Capitol police officers in 1998, in an incident that was caught on videotape. ${ }^{11}$ But the important state interest at stake still must be articulated. Because Weston is mentally ill and dangerous, for example, he is likely to be civilly committed for a long time - at least until he is no longer a danger to others. Thus, a criminal trial is not necessary to promote public safety. Public retribution is important, but it may not be important enough to justify forced medication just for the sake of a trial.

Antipsychotic drugs can have serious effects, including some that can undermine the fairness of a trial. In this regard, Justice Anthony Kennedy argued in a concurring opinion in Riggins that antipsychotic medication should never be ordered for the restoration of competence unless the state can demonstrate that the medication would not alter the defendant's behavior in a way that might prejudice his or her right to a fair trial. In Kennedy's words, "if the defendant cannot be tried without his behavior and demeanor being affected in [a] substantial way by involuntary treatment, in my view the Constitution requires that society bear this cost in order to preserve the integrity of the trial process."

The second reason this case has attracted attention is that it raises the question of whether drugs that affect the mind (and consequently competence) should be treated differently from drugs that affect only bodily function. Sell's supporters argued that forced medication implicated Sell's First Amendment and Fifth Amendment rights to be free from governmental control of his thoughts and emotions, as well as his ability to communicate with his lawyers. They invoked Orwell's 1984 as an image of government run amok and based on fear and mind control, including the vision of "big brother" determining how citizens should think. They also cited the forced drugging of political prisoners in the former Soviet Union and reportedly in China today. ${ }^{12}$

The American Psychiatric Association, on the other hand, took the position in its amicus brief, as it had in Riggins, that "antipsychotic medication should be treated [just] like other medication."13 Were these medications treated as all others are, however, they could never be forced on a competent patient. In fact, the American Psychiatric Association is almost alone in its basic position that seriously mentally ill patients should be forcibly medicated as a matter of course, if necessary, to put them on the road to recovery. The problem with this argument is that psychotropic medication is not just like other medications, because the brain is not just like any other organ. Brain function determines competence, and only psychotropic medications have the potential to make a person competent to stand trial. The Court quite properly rejected the American Psychiatric Association's argument on this point.

All these considerations are based on the assumption that an accurate diagnosis has been made and that the available medications have a reasonable likelihood of restoring competence to stand trial. Questions of diagnostic accuracy, treatment efficacy, side effects, competence, and informed consent are all central to the role of physicians who are involved in the forcible medication of accused persons. In this case, there was credible psychiatric testimony, summarized in the opinion of the court of appeals, that questioned the strength of the evidence of the efficacy of psychotropic medication in treating the type of delusional disorder that had been diagnosed in Sell..$^{5}$ Even the psychiatrists who testi- 
fied for the state could not promise much success; one said he had a 75 percent success rate, and the other claimed only a 50 percent success rate. ${ }^{5}$

THE ROLE OF PHYSICIANS

In Sell, as in Harper and Riggins, the Court accepted the possibility of forced medication in limited circumstances, because the justices usually believe that psychiatrists will only prescribe those psychotropic medications that they consider to be in a defendant's best medical interests. The Court's presumption is that physicians would not act against the interests of their patients, even their patients who are prisoners. Even psychiatrists such as Alan Stone, who support forced medication that will restore competence in general, think it should be used only "to restore the person's mental health" and not for the "needs of the criminal justice system." 10

Similarly, a report by Physicians for Human Rights on the problem of dual loyalty concluded that "the health professional must place the protection of the patient's human rights and well-being first whenever there exists a conflict between the patient's human rights and the state's interest." ${ }^{14}$ The report is a bit vague, and professional standards are often couched in ambiguous language. Thus, forensic psychiatrists and prison physicians may feel that they can determine what is appropriate behavior for themselves in specific instances. They all may understand intellectually that the needs and interests of the state's criminal-justice system should never be placed before the needs and interests of their individual patients. However, because of their own identification with the state, which employs them, they may be able to persuade themselves too easily that the two are not really in conflict. ${ }^{9}$ As Justice John Paul Stevens noted in a dissenting opinion in
Harper, prison psychiatrists are likely to have an institutional bias, and thus "the mere fact that a decision is made by a doctor does not make it certain that professional judgment in fact was exercised."

The Supreme Court cannot resolve the forensic psychiatrist's dual-loyalty conflict; it has only highlighted the conflict by extending the circumstances under which mentally ill persons who are competent to refuse medication can legally be forcibly medicated. Nonetheless, psychiatrists can respond by taking the Court at its word that competent adults should not be involuntarily medicated solely for the convenience of the state, even when such "treatment" is judicially sanctioned. Drugs should be prescribed by a physician only if the physician makes an independent judgment that treatment is in the patient's best medical interests.

From the Department of Health Law, Bioethics, and Human Rights, Boston University School of Public Health, Boston.

1. Annas GJ. The rights of patients. 3rd ed. Carbondale: Southern Illinois University Press, 2004:277-92.

2. Cantor NL. Twenty-five years after Quinlan: a review of the jurisprudence of death and dying. J Law Med Ethics 2001;29:182-96.

3. Grisso T, Appelbaum PS. Assessing competence to consent to treatment: a guide for physicians and other health professionals. New York: Oxford University Press, 1998:27.

4. United States v. Sell, 539 U.S. 166 (2003).

5. United States v. Sell, 282 F.3d 560 (8th Cir. 2002).

6. Dusky v. United States, 362 U.S. 402 (1960).

7. Washington v. Harper, 494 U.S. 210 (1990).

8. Riggins v. Nevada, 504 U.S. 127 (1992).

9. Annas GJ. One flew over the Supreme Court. Hastings Cent Rep 1990;20(3):28-30.

10. Stone A. The right to refuse treatment: Sell v. United States. Psychiatric Times. September 1, 2003:1.

11. United States v. Weston, 255 F.3d 873 (D.C. Cir. 2001).

12. Schlafly P. Forced drugging by government. Eagle Forum. March 27, 2002

13. Amicus brief in United States v. Sell, December 19, 2002. Arlington, Va.: American Psychiatric Association, 2002.

14. International Dual Loyalty Working Group. Dual loyalty \& human rights in health professional practice: proposed guidelines \& institutional mechanisms. Boston: Physicians for Human Rights, 2003. Copyright () 2004 Massachusetts Medical Society. 